\title{
Synthesis of 4-[4-(4-nitrobenzylideneiminophenylene)phenyleneimino methylidene] phenol
}

\section{Marin*, V. Cozan}

Romanian Academy, “Petru Poni” Institute of Macromolecular Chemistry, Aleea Gr. Ghica Voda 41A, Iasi 700487, Romania, Phone: 0232-260332, Fax: 0232-211299, E-mail: lmarin@icmpp.ro

*Author to whom correspondence should be addressed;

Received: 26 October 2006 / Accepted: 13 January 2006 / Published: 1 September 2006

Keywords: azomethine, liquid crystal, phenolic intermediate, thermotropic, nematic

The azomethine $\mathbf{1}$ was prepared as described elsewhere [1]. The 4-[4-(4-nitrobenzylideneiminophenylene)phenyleneimino methylidene] phenol (2) was obtained in a similar manner [2] by reacting the azomethine $\mathbf{1}$ with 4-nitrobenzaldehyde in stoichiometric ratio:

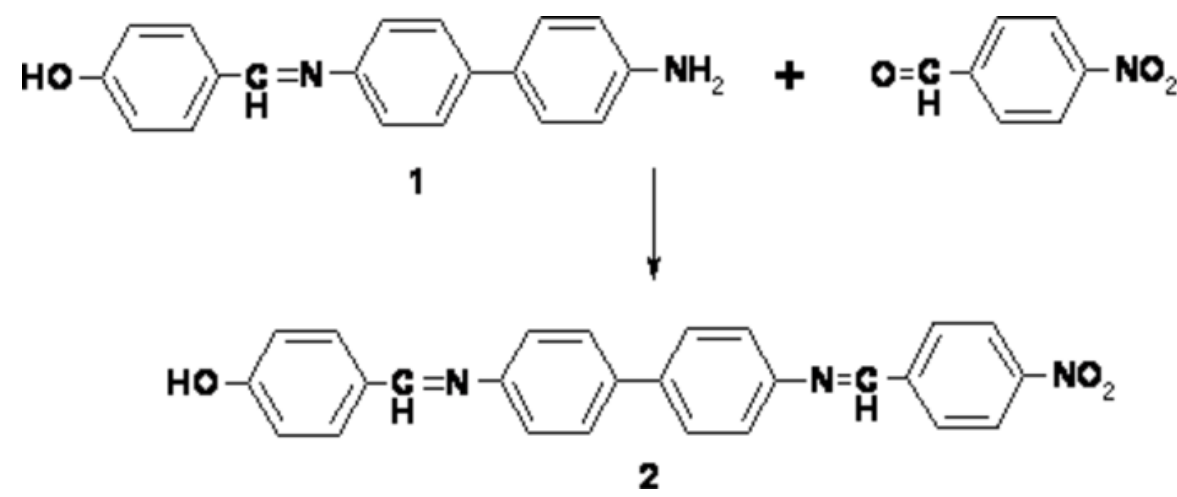

A mixture of $0.8 \mathrm{~g}$ (2.88 mmol) 1 and $0.42 \mathrm{~g}$ (2.77 mmol) 4-nitrobenzaldehyde was dissolved in $10 \mathrm{~mL}$ DMSO. The mixture was stirred under heating at $90{ }^{\circ} \mathrm{C}$ for $30 \mathrm{~min}$. The reaction product was isolated by pouring the reaction mixture into water, washing with water and then with methanol. The purity was tested by the thin layer chromatography. IR spectra and elemental analysis confirmed that synthesised compound had the correct structure with a good degree of purity. The azomethine 2 has an orange-ochre powder aspect, yield $80 \%$.

Mp. $213{ }^{\circ} \mathrm{C}$ (by polarization light microscopy), $212{ }^{\circ} \mathrm{C}$ (by thermooptical analysis), $215{ }^{\circ} \mathrm{C}$ (by DSC method). In the melting state the product exhibit liquid crystalline behavior displaying a typical schlieren texture (see Figure 1). The isotropisation temperature could not be measured, because the decomposition started before (decomposition temperature $\mathrm{T}_{0}=256^{\circ} \mathrm{C}$ )

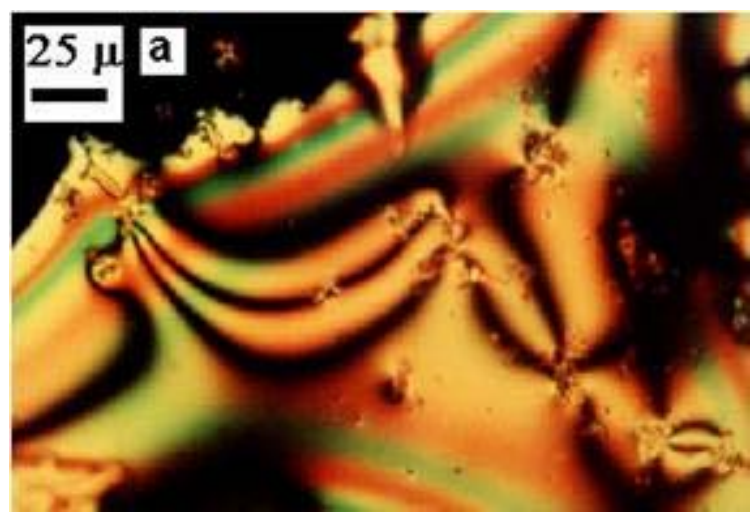


Figure 1. The schlieren texture of azomethine 2 at $246{ }^{\circ} \mathrm{C}$, between crossed polarizers UV (DMF) 286, $382 \mathrm{~nm}$

Anal. calc. for $\mathrm{C}_{26} \mathrm{H}_{19} \mathrm{~N}_{3} \mathrm{O}_{3}$ (421.45): $\mathrm{N} \%$ 9.97; found: $\mathrm{N} \% 9.52$

IR (KBr, $\left.\mathrm{cm}^{-1}\right)$ : $3450(\mathrm{O}-\mathrm{H}), 1625(\mathrm{CH}=\mathrm{N}), 1600,1580(\mathrm{C}=\mathrm{C}), 1520\left(\mathrm{NO}_{2}\right.$ asym.), $1450(\mathrm{C}=\mathrm{C}), 1350$ ( $\mathrm{NO}_{2}$ sym.), 1240 (C-O, asym.), 1160 (C-O, sym.), 855, 840 (1,4-phenylene ring).

\section{References:}

1. V. Cozan, E. Avram Eur. Polym. J. 2003, 39, 107-114.

2. C. Racles, V. Cozan, High Performance Polymers 2002, 14, 169-181.

(C) 2006 MDPI. All rights reserved. 